$$
\text { チャノコカクモンハマキとチャハマキの (Z)-11- }
$$

tetradecenyl acetate による同時交信攪乱

農林水産省茶業試験場
大泰 司 誠
静岡県茶業試験場
堀 川 知 廣*

\title{
Simultaneous Disruption of Pheromonal Communication of the Smaller Tea Tortorix Moth and the Tea Tortorix Moth with (Z)-11-Tetradecenyl Acetate
}

\author{
By Makoto OHTAISHI and Tomohiro HORIKAWA* \\ National Research Institute of Tea \\ * Shizuoka Tea Experiment Station
}

チャノコカクモンハマキ(Adoxophyes sp.) とチャハ マキ(Homona magnanima DIAKONOFF) は活漂同じ時 期に発生するため，合成性フェロモンを利用した防除も 同時防除であることが好喆しい（）。雨種の性フェロモンは それぜれ4 成分および 3 成㞣の化合物によって構成され ており，それぞれの性フェロモンに共通する成分である (Z)-11-tetradecenyl acetate ( Z 11-14 Ac) によって

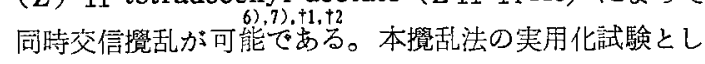

て大面積の茶園に 1983年と 1984年の 2 年間にわたり適用 しな結果を報告する。

使用した茶園は静岡県島田市船木の 108 のほ場からな る 5 ha の農家茶園である。周囲は道路を隔ててすべて 茶園によって囲をれる。比較対照のための無処理茶園は， 周囲の茶園から6ブロック，100ほ場を任意に選定した （図 1)。処理区の殺虫剂散布は制限はせず，交信攪乱は 上乗せ処理とした。交信挩乱用の蒸散源として $70 \mathrm{mg} の$

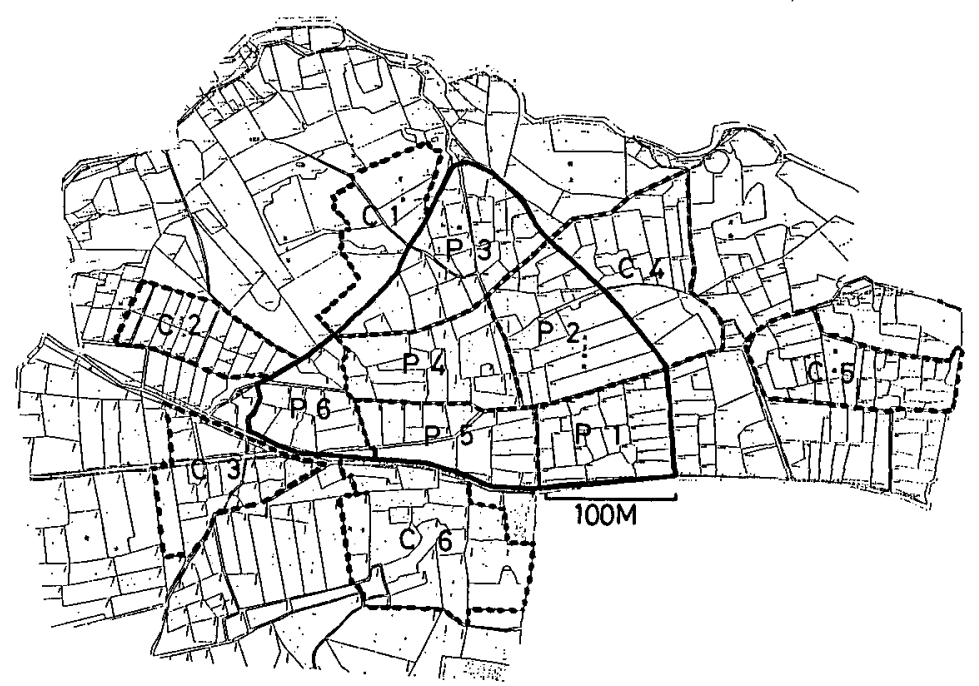

図 1 交信撜乱試験便用した茶園の概略図

P 1 からP 6 のブロックは交信窑乱区

C 1 からC 6 のブロックは無処理対照区

$\dagger 1$ 大泰司 誠：昭和58年度フェロモン利用に関するシンポジウム講要，日本植物防没協会，41〜59 (1983).

†2 堀川知廣: 同, 60 77 (1983)。 
Z11-14Ac を封入した内径 $0.8 \mathrm{~mm}$ ， 外径 $1.6 \mathrm{~mm}$, 镸さ $20 \mathrm{~cm}$ のポリエ チレンチューブを使用し，茶樹の摘 採面から 10〜20 cm下方に取りつけ た。1983年は第 1 回成虫発生前の 4 月 8 日に, 全ての茶歡に $1 \mathrm{~m}$ の間隔 で 1 ha あたり 6,000 本を取り付け， 第 2 第 4 回発生期前の 6 月 20 日, 8 月 5 日, 9 月 $26 \cdot 27$ 日にそれぞれ $1.5 \mathrm{~m}$ の間隔で 1 ha あたり 4,000本 を追加した。Z 11-14 Ac の蒸散量 は第 1 ～第 4 回発生期についてそれ ぞれ $2.7 \sim 4.4,2.7 \sim 6.5,8.4 \sim$ 13.7,2.5 4.1g/day/haであった。 この年の結果から年間 3 回の取り付 けで $3.5 \mathrm{~g} / \mathrm{day} / \mathrm{ha} の$ 必要量の蒸散 が得られると判断し，1984年は 4 月 18 日に $1 \mathrm{~m}$ 間隔で取りつけた後， 6 月26日と 9 月 14 日に $1.5 \mathrm{~m}$ の間隔で 追加した。蒸散量は第 $1 \sim 4$ 回発生 期についてそれぞれ3.0〜3.5，5.3 $\sim 8.7,5.4,2.7 \mathrm{~g} / \mathrm{day} / \mathrm{ha}$ であっ た。

処理区内に置いたモニタリングト ラップの雄成虫の年間の付着数を表 1 亿示した。性フェロモンを馀引源 としたトラップの付着数は他種の性 フェロモンあるいはブランクのトラ ップの付着数よりる多く, 性フェロ モンへ誘引されていたと考党られる が, 無処理区の誘引数と比較する と0.04〜 1.8\%とわずかであり, 高 い誘引阻害効果が得られた。

表 2 亿発生最盛日の前後棌集し た倠成虫の交尾率を示した。両種と る飞交尾雌率は撜乱処理によって低 下して叔り，チャハマキに対する勃 果がチャノコカクモン八マキに対す る効果よりす高い。ここで示す交尾 雌率は交尾闵の雌が茶園内に累積さ れていたすのを採集した結果であ るため, 1 日めたりの交尾阻害率は この值よりもさら高い。また交尾 阻害によって交尾か遅延することに より産卵数は減少することが報告されている。従って， 実質的な防除率にあたる産卵抑制率は，ここで示した交 尾阻害率の平均值であるチャノコカクモン八マキ38.7 \%、チャハマキ52.3\%よりかなり高いと考兄られる。
表 1 交信筧乱区のモニタリングトラップに打ける雄成虫の付着数

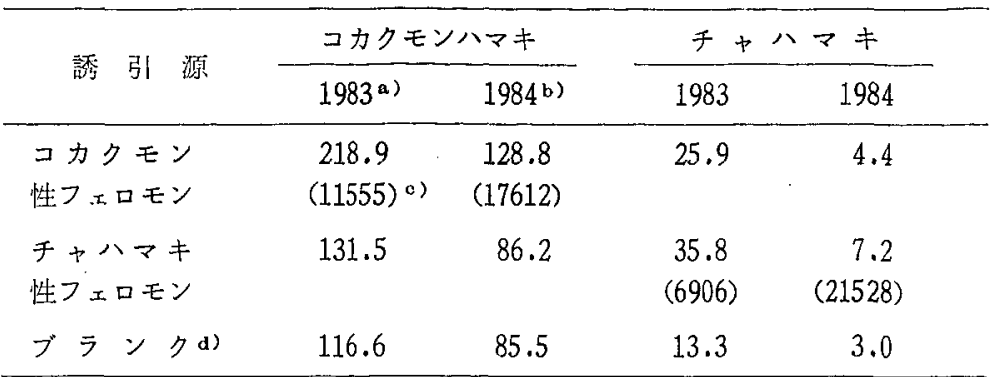
a) 4 月 8 日から10月14日までの総付着数の8トラップの平均値
b) 4月18日から10月30日までの総付着数の5トラップの平均值
c) 無処理区のフェロモントラップの誘殺数
d）誘引源なしのトラップ

表 2 交信攪乱区括よび無処理区における倠成虫の交尾率

\begin{tabular}{|c|c|c|c|c|c|c|c|c|}
\hline \multirow[b]{2}{*}{ 年 } & \multirow{2}{*}{ 発生期 } & \multirow{2}{*}{ 処理 } & \multicolumn{3}{|c|}{ コカクモンハマキ } & \multicolumn{3}{|c|}{ チャハマキ } \\
\hline & & & 調査数 & $\begin{array}{l}\text { 交尾雌 } \\
\text { 率 } \% \text { ) }\end{array}$ & $\begin{array}{l}\text { 交尾䪶害 } \\
\text { 率 }(\%)\end{array}$ & 調查数 & $\begin{array}{l}\text { 交尾䧳 } \\
\text { 率 }(\% \%)\end{array}$ & 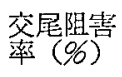 \\
\hline \multirow[t]{6}{*}{1983} & 1 & 処 理 & 1386 & 62.6 & 32.0 & 64 & 42.2 & 57.8 \\
\hline & & 無処理 & 101 & 95.1 & 一 & 8 & 100.0 & - \\
\hline & 2 & 処 理 & 441 & 46.9 & 46.5 & 14 & 42.9 & 26.5 \\
\hline & & 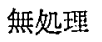 & 130 & 87.7 & - & 24 & 58.3 & 一 \\
\hline & 3 & 処 理 & 249 & 49.0 & - & 20 & 25.0 & 一 \\
\hline & $4 b)$ & - & & & & & & \\
\hline \multirow[t]{6}{*}{1984} & 1 & 処 理 & 320 & 60.6 & 36.9 & 216 & 30.1 & 66.2 \\
\hline & & 無処理 & 99 & 96.0 & - & 91 & 89.0 & - \\
\hline & 2 & 処 理 & 376 & 52.1 & 39.2 & 81 & 25.9 & 58.7 \\
\hline & & 理処理 & 160 & 85.6 & - & 59 & 62.7 & - \\
\hline & 3 b) & - & & & & & & \\
\hline & 4 b) & - & & & & & & \\
\hline
\end{tabular}

a) 交尾阻害率=（1-処理区交尾唯率／無処理区交尾雌率 $) \times 100$

b) 発生数が少く調查できなかった。

表 3 交信㨨乱区と無処理区の越冬幼虫密度 $\left(\bar{x} \pm \mathrm{S} . \mathrm{E} . / 0.5 \mathrm{~m}^{2}\right)$

\begin{tabular}{|c|c|c|c|c|c|c|}
\hline \multirow{2}{*}{ 処 } & \multirow{2}{*}{ 理 } & \multirow{2}{*}{$\begin{array}{c}\text { 調查 }^{\mathbf{a}} \\
\text { 伜数 }\end{array}$} & \multicolumn{2}{|c|}{ コカクモンハマキ } & + & \multirow{2}{*}{$\frac{7 \text { キ }}{1984}$} \\
\hline & & & 1983 & 1984 & 1983 & \\
\hline 処 & 理 & $\begin{array}{c}432 \\
(424)\end{array}$ & $3.12 \pm 0.29$ & $7.65 \pm 0.59$ & $5.45 \pm 0.44$ & \\
\hline 無久 & & $\begin{array}{c}412 \\
(416)\end{array}$ & $17.52 \pm 1.43$ & $13.56 \pm 1.30$ & $16.56 \pm 1.09$ & $31.71 \pm 2.51$ \\
\hline
\end{tabular}

a) 調查は 1 ほ場あたり $0.5 \times 1 \mathrm{~m}$ の枠を用いて 4 柲調査した。改植等によ り年度によって枠数は巽なり，（）は1984年の調查枠数を示す。 処理と無処理の間にはいずれも5\%の佮率で有意差あり。

表 3 亿処理 1 年後と 2 年後の越冬期の幼虫密度を示し た。両年とす両種の密度は無処理区に比較し有意に低下 した。また無処理区にみられるよ5な極めて高密度の多 発生ブロックは処理区内では認められない（図2)。無 

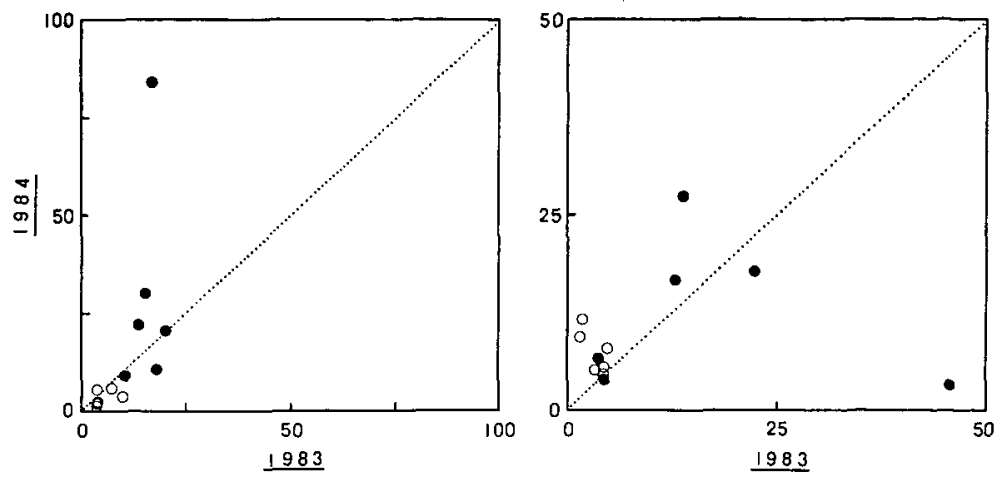

图 2 ブロック別の1983年と1984年の越冬幼虫密度の関係 $\left(\bar{x} / 0.5 \mathrm{~m}^{2}\right)$

左：チャハマキ, 右：チャノコカクモン八マキ

: 無处理ブロック (C 1〜C 6), O：処理ブロック（P1〜P 6)

処理区に括けるチャハマキ密度は1984 年には増加する傾 向にあったが，処理区では逆に減少したブロックが多く， 2 年間連続して減少する結果となり，その減少率も大き い(図2)。一方，チャノコカクモン八マキの場合は1983 年の無処理区の密度が高かったため，渨処理区内のブロ ックに拈いては 3 ブロックで減少したが，処理区内にお いては低密度に抑制されていたるののすべてのブロック に扒いて增加する結果となった（図2）。

再年ともに越冬世代以外の幼虫密度の調查は行って扔 らず，薬剂散布への上乗せ処理てあるために，交信撜乱 によって楽剤による防除が不要な程度をで密度を抑制す ることができるかどうかは不明である。特にチャノコカ クモンハマキに対しては，試験潘場が八マキガ類の多発 生地域でったため薬剤による防除が必要と思われた活 場も散見され，効果は不十分であるかもしれない。しか しながら，本交信攪乱法を継続して使用し，言わば環境 抵抗として利用するならば，両八マキガの異常発生を末 然仿ぐことができ，特にチャハマキに対する効果はす ぐれていると考穴られる。

ここに用いた製剂を供与された信越化学工業株式会社 に扮礼を申し上げる。

\section{引用 文 献}

1) TAMakI, Y., H. Noguchi, T. Yushima and C. Hirano : Appl. Ent. Zool., 6, 139 141 (1971).

2) Tamaki. Y., H. Noguchi, H. Sugie, R. Sato and A. KARIYA : Appl. Ent. Zool. 14, 101 113 (1979).

3）玉木佳男, 野口 浩, 杉江 元, 则屋 明, 新井 茂, 大場正明, 寺田孝重, 勝呂利男, 菻 謙治: 応 動昆，24，22１228（1980）。

4) Noguchi, H., Y. Tamaki and T. Yushima:
Appi. Ent. Zool., 14, 225 228 (1979).

5）野口 浩, 玉木佳男, 新井 茂, 下田美智子, 石川 㦑：応動昆, 25, 170 175 (1981).

6) Ohtaishi, M. and T. Horikawa : Proc. Ist Japan/U. S. A. Symp. on IPM, Tsukuba, Sep. 29 30, 41 49 (1981).

7）玉杢佳男, 野口 浩, 杉汇 元：応動屁，27，124～ 130 (1930).

8）加納昌彦, 桐谷圭治, 川崎建次郎：応動昆, 27, $40 \sim 45$ (1983).

\section{Summary}

Simultaneous communication disruption for suppression of the smaller tea tor torix moth, Adoxophyes sp., and the tea tortorix moth Homona magnanima with (Z)-11-tetradecenyl acetate, the common pheromonal component of the two species, was conducted for 2 year (1983-1984) on 5-ha nonisolated commercial tea fields. Rate of evaporation was 2.5 to $13.7 \mathrm{~g} / \mathrm{day} / \mathrm{ha}$. Inhibition rate of male attraction, which was monitored with pheromone traps, was high ranging 98.2 to $99.3 \%$ for Adoxophyes and 99.5 to $99.96 \%$ for Homona. Mating of females of Adoxophyes and Homona in the pheromone-treated fields were reduced $32.0-39.2 \%$ and $26.5-66.2 \%$ from those of control fields, respectively. in the 1 st year, the density of the overwintering Iarvae of Adoxophyes in the treated field was reduced to $17.8 \%$ of that of the control fields and $56.4 \%$ in the 2nd year. And those of Homona were $32.9 \%$ and $7.4 \%$ respectively.

(June 17, 1985) 